\author{
제주지역에서 사육중인 더러브렛 종빈마의 여름철 방목행동에 \\ 관한 연구
}

전병태 · 김명화 · 박재현 · 이상무* · 성시흥 · 김성진 · 문상호

\title{
A Study on the Grazing Behavior of Thoroughbred Mares Grazed in Pasture at Summer Season of Jeju Island
}

Byong Tae Jeon, Myeong Hwa Kim, Jae Hyun Park, Sang Moo Lee*, Si Heung Sung, Sung Jin Kim and Sang Ho Moon

\begin{abstract}
This research was conducted to investigate the group and individual behavioral patterns of thoroughbred mares which are important for raising race-horses, in paddoks (pregnant) and pastures (nursing). In a group of nursing mare, eating $62 \%$, standing resting $31 \%$, drinking $3 \%$, lying resting $1 \%$, walking $1 \%$ and nursing $2 \%$ were observed, although no running was observed. Average time spent on individual behavior of mares (3 heads) was eating $295 \mathrm{~min}(55 \%)$, standing resting $193 \mathrm{~min}(36 \%)$, walking $18 \mathrm{~min}$, drinking 18 $\min (3 \%)$, nursing $13 \mathrm{~min}(2 \%)$, lying resting $6 \mathrm{~min}(1 \%)$. Average 11 times of grooming, 2 times of urinating, and 1 time of feces were observed for mare in pasture. $48 \%$ of standing resting, $44 \%$ of eating, $2 \%$ of lying resting, $4 \%$ of walking, and $2 \%$ of drinking were revealed for pregnant mares in paddock. Average individual behavioral pattern of pregnant mares (3 heads) was $52 \%$ of eating, $40 \%$ of standing, $6 \%$ of walking, and $2 \%$ of drinking. Average 15 times of grooming, 1 time of urinating, 3 times of feces, 1 time of fighting, and 2 times of rolling were observed for pregnant mares in paddock. For moving patterns, pregnant mares were inclined to concentrate on where the nearby paddok is close to.
\end{abstract}

(Key words : Thoroughbred, Mare, Nursing, Pregnant, Behavioral pattern, Pasture, Paddock)

$$
\text { I. 서 론 }
$$

자연환경에서 말은 동종의 개체들과 밀접한 관계를 맺으며 많은 시간을 소비하는 사회적인 동물이다. 말들 사이의 communication은 무리에 서의 결합과 안전을 위하여 필수적이며 (Waring
등, 1975) 말은 다양한 얼굴표정 (Schafer, 1975), 몸짓 (Tyler, 1972; Feist와 McCullough, 1976), 발성을 이용하여 그들의 의사를 전달한 다 (Houpt, 1977). 말무리에서 사회적인 촉진은 한 동물에 의해서 나타나는 본능적 행동 양식 이 같은 행동에 대하여 다른 동물에게 자극으

건국대학교 녹용연구센터 (Korea Nokyoug Research Center, Konkuk University, 322 Danwol, Chungju, 380-701, Korea)

* 경북대학교 (Kyongpook National University, Sangju, 742-711, Korea)

Corresponding author: Sang Ho Moon, Department of Animal Science, College of Natural Sciences, Konkuk University, Chungju, 380-701, Korea, Tel: +82-43-840-3527, Fax:+82-41-580-2222, E-mail: moon0204@kku.ac.kr 
로 작용하여 결국엔 동일한 형태의 행동양식이 전체 무리에서 나타나게 된다(Thorpe, 1963). 사람에 의하여 사육되는 상태에서 말들은 대개 개개의 마방이나 운동장에서 독립적인 생활을 하게 되는데 이로 인한 사회적인 접촉의 부족 은 말들에게 심한 스트레스로 작용한다 (Luescher 등, 1991). 이러한 스트레스를 줄여주 고 운동의 장을 제공함과 동시에 그들에게 적 합한 채식생리 욕구를 충족시켜 주기위해 말 사육에서 방목은 거의 필수적이라 할 수 있다. 특히 종빈마와 임신마는 임신과 출산, 포유라 는 생리적인 현상을 거치는 만큼 사회적인 촉 진과 행동이 일반마와 다를 수밖에 없을 것이 다.

말의 행동은 크게 채식행동, 이동행동, 음수 행동, 휴식 (기립, 횡와)행동, grooming, 투쟁행 동, 배뇨 및 배설행동 등으로 나누어 볼 수 있 다. 채식행동은 일반적인 활동이나 동물의 영 양 상태와 관련이 있고 방목기간 중 채식시간 은 계절 (Crowell-Davis 등, 1985; Tsujii와 Moro, 1987), 말의 연령 (Tsujii와 Asai, 1985), 사료의 질, 기온 등의 요인에 다라 달라질 수 있다 (三 村, 1988). 방목지 목구의 크기도 방목행동에 영향을 미친다 (Sheppard, 1921). 미국, 유럽과 같은 외국에서는 운동장의 크기에 따른 말의 행동 연구 (Grete와 Knut, 2007), 채식, 배설 및 휴식에 관한 연구(Carson과 Wood-Gush, 1983) 및 사회적 순위에 따른 성행동 발현에 관한 연 구 (Filipa 등, 2006) 등 다각적인 측면에서 효율 적인 방목지 설계를 위하여 말의 행동에 관한 연구를 하고 있다.

현재 국내에서는 경주용 육성마와 재래마 목 장이 제주도를 중심으로 많이 운영되고 있는데 정확한 목구의 크기나 관리형태 등에 대한 정 보가 부족하고 말방목에 대한 연구도 매우 한 정적으로 수행되고 있는(정 등, 1994; 강 등, 1996 ) 상황으로, 말의 생리적 상태나 환경에 따
른 방목행동 패턴에 관한 연구가 매우 부족한 실정이다.

따라서 본 연구는 제주도의 경주용 말을 생 산하는 농장에서 종빈마 중 일반 패독에서 사 육 중인 임신마 및 방목지에서 사육 중인 포유 마의 행동패턴을 개체 및 군별로 조사하여 향 후 말 방목관리를 위한 기초자료를 얻기 위하 여 실시하였다.

\section{ㅍ. 재료 및 방법}

\section{1. 공시동물과 사양관리}

포유 및 임신 중인 더러브렛종 종빈마의 방 목행동을 제주도에 위치하고 있는 중앙 목장에 서 2007년 6월 23일부터 6월 29일까지 육안 관 찰에 의해 측정하였다. 공시마는 포유 종빈마 9두와 이들의 자마 9두 (3 6개월령) 그리고 임 신 종빈마 9두를 각각 공시하였다. 일상적으로 방목지에 방목 중인 포유 종빈마에게는 알팔파 $4 \mathrm{~kg}$ /두/일과 농후사료 $4 \mathrm{~kg}$ /두/일을 하루에 2회 기초사료로 제공하였다. 급여사료의 일반성분 을 Table 1에 나타내었다.

본 실험을 실시한 목장은 제주지역에서 말 목장의 방목지의 초지 품종으로 권장되고 있는 Kentucky bluegrass를 파종하여 초지를 조성하 여 사용하고 있으며 불식과번지의 확대와 초지 의 불량을 막기 위하여 매년 겉뿌림을 하여 초 지를 관리하고 있었다. 초지 구성은 Kentucky bluegrass (품종) 단파 초지였으며, $25 \mathrm{~cm}^{2}$ 면적의 틀을 설치, 방목지 전체에서 무작위로 15 군데 의 초지를 낫으로 베어 방목지의 평균 목초수 량을 현물량으로 측정하였다. 방목장의 면적은 $6.62 \mathrm{ha}$ 로 초고는 평균 $30 \pm 5.7 \mathrm{~cm}$ 였고 목초수량 은 $86.2 \pm 23.4 \mathrm{~g} / 25 \mathrm{~cm}^{2}$ 였다. 패독에서 사육 중인 임신 종빈마에게는 알팔파와 이탈리안 라이그 라스 $6 \sim 8 \mathrm{~kg}$ /두/일과 농후사료 $6 \mathrm{~kg}$ /두/일을 하 
Table 1. Chemical composition of diet fed to experimental animal

\begin{tabular}{|c|c|c|c|}
\hline Item & Concentrates & Italian Ryegrass & Alfalfa \\
\hline \multicolumn{4}{|c|}{ 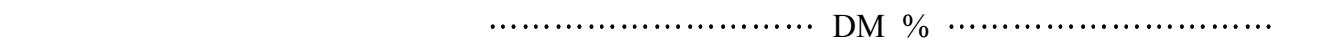 } \\
\hline Crude protein & $15.0 \pm 0.17$ & $17.17 \pm 0.57$ & $14.34 \pm 0.58$ \\
\hline Crude fiber & $12.5 \pm 0.08$ & $35.33 \pm 0.35$ & $37.95 \pm 0.43$ \\
\hline Ether extract & $2.0 \pm 0.03$ & $2.58 \pm 0.09$ & $1.69 \pm 0.21$ \\
\hline Crude ash & $10.0 \pm 0.09$ & $11.05 \pm 0.01$ & $10.43 \pm 0.05$ \\
\hline
\end{tabular}

루에 2회로 나누어서 급여하였다. 패독(운동 장)은 운동과 거주 및 사료채식을 위한 공간으 로서 시험마에게 제공된 페독의 면적은 1,892 $\mathrm{m}^{2}$ 이었다.

행동관찰을 실시한 날의 기상조건을 Table 2 에 나타내었다. 행동관찰을 실시한 날의 날씨 는 하루 종일 맑았으며 평균 기온은 $26^{\circ} \mathrm{C}$, 평 균 습도는 $72.0 \%$ 였다.

\section{2. 행동관찰}

방목 중인 포유 종빈마군은 일상적인 방목관 리 조건 하에서 행동을 관찰하였고 패독에 사 육 중인 임신 종빈마군은 최소 1 주일간의 일상 관리 조건 후에 행동을 관찰 하였다. 방목지 및 패독에서 군 관찰과 개체 관찰을 통해 행동 패턴을 조사하였으며, 행동관찰은 09시부터 18 시까지 9시간 동안 지속적으로 실시하였다. 개 체관찰을 위해 각 군에서 3 두씩의 개체를 선정 하였고 관찰자는 각 개체마다 두 사람을 선정
하여 3 시간마다 교대로 지속적인 관찰을 실시 하였으며, 개체 관찰과 별개로 군 행동을 조사 하기 위해 별도의 관찰자가 군 전체에 대한 10 분 간격의 관찰을 실시하였다. 관찰은 모눈종 이를 활용하여 기록하였고 기온 및 습도와 풍 속관찰을 온습도 등을 이용하여 실시하였다.

\section{3. 행동관찰 조사 항목}

행동관찰 기간 중에 나타나는 각 행동형을 조사하였으며, 채식, 음수, 휴식 (기립, 횡와), 보행 및 running 행동은 시간 단위로 기록하였 고 grooming, 투쟁, 뒹굴기, 배뇨 및 배설 행동 은 발현된 횟수로 기록하였다.

말의 행동은 다른 행동과 수반되어 일어나는 경우가 많으므로 실제로 한 가지의 행동을 하 기 위한 선구행동과 더불어 행동시간을 육안으 로 기록하는 것은 쉽지 않으므로 한 행동이 일 어나기 위한 선구행동 시간은 측정하기 않았 다. 따라서 채식은 말이 풀을 뜯는 행동을 하

Table 2. Ambient condition of experimental field

\begin{tabular}{lcccccccccc}
\hline \multirow{2}{*}{ Item } & \multicolumn{10}{c}{ Hour } \\
\cline { 2 - 10 } & $9: 00$ & $10: 00$ & $11: 00$ & $12: 00$ & $13: 00$ & $14: 00$ & $15: 00$ & $16: 00$ & $17: 00$ & $18: 00$ \\
\hline \hline Temperature $\left({ }^{\circ} \mathrm{C}\right)$ & 29.2 & 29.8 & 28.5 & 27.9 & 28.3 & 29.5 & 28.9 & 28.7 & 30.0 & 29.5 \\
Humidity (\%) & 85 & 84 & 72 & 68 & 63 & 63 & 68 & 70 & 74 & 72 \\
Wind speeds (m/s) & 1.7 & 0.9 & 2.0 & 1.1 & 1.5 & 1.6 & 1.5 & 2.0 & 1.1 & 1.3 \\
\hline
\end{tabular}


는 시간과 급여한 사료를 먹는 시간을 측정하 였고 음수행동은 급수장을 향해 이동하는 시간 등 물을 마시기 위한 선구행동은 제외하고 관 찰한 9시간 동안 실제로 물을 섭취하는 시간과 물을 섭취한 후의 행동을 합산하였으며, 휴식 은 다른 행동은 하지 않고 가만히 서있는 시간 과 옆으로 누워있는 시간, 보행은 음수를 위하 여 이동하거나 방목지에서 위치를 바꾸기 위하 여 이동하는 등 실지로 걷는 시간을 모두 합산 하였다. 또한 running 행동은 방목지에서 이동 을 위해서나 다른 말에게 다가가기 위해서 실 제로 달리는 행동을 한 시간을 측정하였다.

\section{III. 결과 및 고찰}

Table 3에 방목지에서 포유 중인 종빈마의
개체 및 군 행동발현 시간과 비율을 나타내었 다. 종빈마군에서는 채식비율이 $62 \%$, 기립 휴 식 비율 $31 \%$, 횡와 휴식 비율 $1 \%$, 음수 비율 $3 \%$, 보행 비율이 $1 \%$ 였고 러닝 행동은 관찰 기 간 중 발현되지 않았다. 수유 행동은 $2 \%$ 가 발 현되었는데 수유와 동시에 종빈마의 채식행동 이 이루어지는 경우도 있었다. 종빈마 개체별 행동발현은 채식이 평균 295 분으로 $55 \%$, 기립 휴식이 193 분으로 $36 \%$, 보행과 음수가 각각 18 분과 15 분으로 $3 \%$, 수유가 13 분으로 $2 \%$, 횡 와 휴식이 6 분으로 $1 \%$ 였다. 또한 grooming은 11 회, 배뇨는 2회, 배분은 1회로 조사되었다. 본 연구에서 말들은 조사기간의 절반 이상을 채식행동에 소비하고 있는 것으로 나타났고 휴 식비율도 다른 행동에 비하여 높게 나타나 종 빈마는 방목지에서 대부분의 시간을 채식과 기

Table 3. Time and ratio spent on each behavior of mare grazed in pasture

\begin{tabular}{|c|c|c|c|c|c|c|c|c|c|c|c|}
\hline \multirow{3}{*}{ Item } & \multirow{2}{*}{\multicolumn{2}{|c|}{ Eating }} & \multicolumn{5}{|c|}{ Resting } & \multirow{2}{*}{\multicolumn{2}{|c|}{ Walking }} & \multirow{2}{*}{\multicolumn{2}{|c|}{ Running }} \\
\hline & & & \multicolumn{3}{|c|}{ Standing } & \multicolumn{2}{|c|}{ Lying } & & & & \\
\hline & Min. & $\%$ & \multicolumn{2}{|c|}{ Min. } & $\%$ & Min. & $\%$ & Min. & $\%$ & Min. & $\%$ \\
\hline No.1 & 279 & 52 & \multicolumn{2}{|c|}{206} & 38 & 19 & 4 & 16 & 3 & 0 & 0 \\
\hline No. 2 & 274 & 51 & \multicolumn{2}{|c|}{223} & 41 & 0 & 0 & 15 & 3 & 0 & 0 \\
\hline No.3 & 331 & 61 & \multicolumn{2}{|c|}{149} & 28 & 0 & 0 & 23 & 4 & 0 & 0 \\
\hline Avg. & $\begin{array}{c}294.7 \pm \\
31.6\end{array}$ & $\begin{array}{c}54.7 \pm \\
5.5\end{array}$ & \multirow{2}{*}{\multicolumn{2}{|c|}{$\begin{array}{c}192.7 \pm \\
33.8\end{array}$}} & $\begin{array}{c}35.7 \pm \\
6.8\end{array}$ & $\begin{array}{c}6.3 \pm \\
10.9\end{array}$ & $\begin{array}{l}1.3 \pm \\
2.3\end{array}$ & $\begin{array}{c}18.0 \pm \\
4.4\end{array}$ & $\begin{array}{l}3.3 \pm \\
0.6\end{array}$ & 0 & 0 \\
\hline Group & & 62 & & & 31 & & 1 & & 1 & & 0 \\
\hline \multirow[t]{2}{*}{ Item } & \multicolumn{2}{|c|}{ Drinking } & \multicolumn{2}{|c|}{ Nursing } & \multicolumn{2}{|c|}{ Total } & Grooming & Urinating & Feces & Fighting & Rolling \\
\hline & Min. & $\%$ & Min. & $\%$ & Min. & $\%$ & No. & No. & No. & No. & No. \\
\hline No.1 & 12 & 2 & 8 & 1 & 540 & 100 & 9 & 3 & 1 & 0 & 0 \\
\hline No. 2 & 13 & 2 & 15 & 3 & 540 & 100 & 11 & 2 & 2 & 0 & 0 \\
\hline No.3 & 20 & 4 & 17 & 3 & 540 & 100 & 14 & 2 & 1 & 0 & 0 \\
\hline Avg. & $\begin{array}{c}15.0 \pm \\
4.4\end{array}$ & $\begin{array}{l}2.7 \pm \\
1.2\end{array}$ & $\begin{array}{c}13.3 \pm \\
4.7\end{array}$ & $\begin{array}{l}2.3 \pm \\
1.2\end{array}$ & 540 & 100 & $\begin{array}{c}11.3 \pm \\
2.5\end{array}$ & $\begin{array}{l}2.3 \pm \\
0.5\end{array}$ & $\begin{array}{l}1.3 \pm \\
0.5\end{array}$ & 0 & 0 \\
\hline Group & & 3 & & 2 & & 100 & & & & & \\
\hline
\end{tabular}


립 휴식에 소비하는 것으로 나타났다. 각 개체 의 행동과 군 행동 양식도 거의 흡사한 경향을 띄고 있었다. 강 등 (1996)의 연구에 의하면 종 빈마 군에서 채식 행동의 발현은 망아지가 어 릴 때는 (3개월 령) 짧고 성장하면서 (4개월 령) 길어지는 패턴을 나타내며 말의 채식시간은 말 의 품종에 따라 크게 차이가 나타나지 않고 (정 등, 1994), 사료의 질, 방목계절, 기온 등의 요 인에 따라 달라질 수 있으며 초지의 상태에 따 라 달라진다고 보고되고 있다 (三村, 1988).

방목지에서 종빈마의 군별 이동패턴을 Fig. 1 에 나타내었다. 군별 이동 패턴은 오전에 사료 및 물 급여에 따라 방목장 입구에 집중되었으 나 채식과 휴식 및 포유를 위해서는 각기 크게 산개하여 행동하는 경향을 나타내었다. 즉 종 빈마 군에서는 휴식이나 채식 시에 가급적 다 른 개체와 근접하지 않으려고 하는 경향이 강 하게 나타나는 것으로 분석되었다. 본 연구에 서는 종빈마와 자마 간의 거리는 조사하지 않 았으나 관찰시간 내내 그 거리는 크게 벌어지 지 않았다. 종빈마는 다른 개체보다 영역행동 이 더 강하게 나타나며 (Francis-Smith, 1979),
포유 중이거나 휴식 중인 종빈마는 새끼 말들 에게 다른 말이 접근해오면 자마를 보호하기 위해서 위협행동을 나타내며 그 빈도는 새끼말 의 성장과 함께 감소된다(三村, 1988)고 보고 되고 있다. 어미 말이 채식을 하고 있을 때는 그들은 새끼들로부터 평균 $5.05 \mathrm{~m}$ 정도의 거리 를 유지하고 기립 휴식을 하고 있을 때에는, 그 거리가 단지 $0.48 \mathrm{~m}$ 밖에 되지 않았다는 연 구 보고가 있다 (Hector, 1990).

Fig. 2에 시간대 별 방목지에서 포유 중인 종빈마의 군행동과 각 개체별의 행동발현을 나 타내었다. 종빈마의 군 행동에서 채식행동은 오전 11 시 경에만 적었을 뿐 거의 모든 시간대 에 채식행동을 나타내 조사 기간 동안 전체적 으로 고르게 분포되었으나 특히 오전 10시 경 과 오후 2시 3시 경에 채식행동의 발현빈도가 높았다. 그러나 개체별 행동발현에는 개체차가 있어 1 번 개체는 자주 채식을 하였고 2 번 개체 는 오전 11시에서 오후 1 시 경까지는 휴식에 많은 시간을 소비하였으며 채식은 주로 오후에 집중되었고 3 번 개체는 오전 9시부터 오후 3 시 까지 많은 시간을 채식하는데 소비하였다. 종

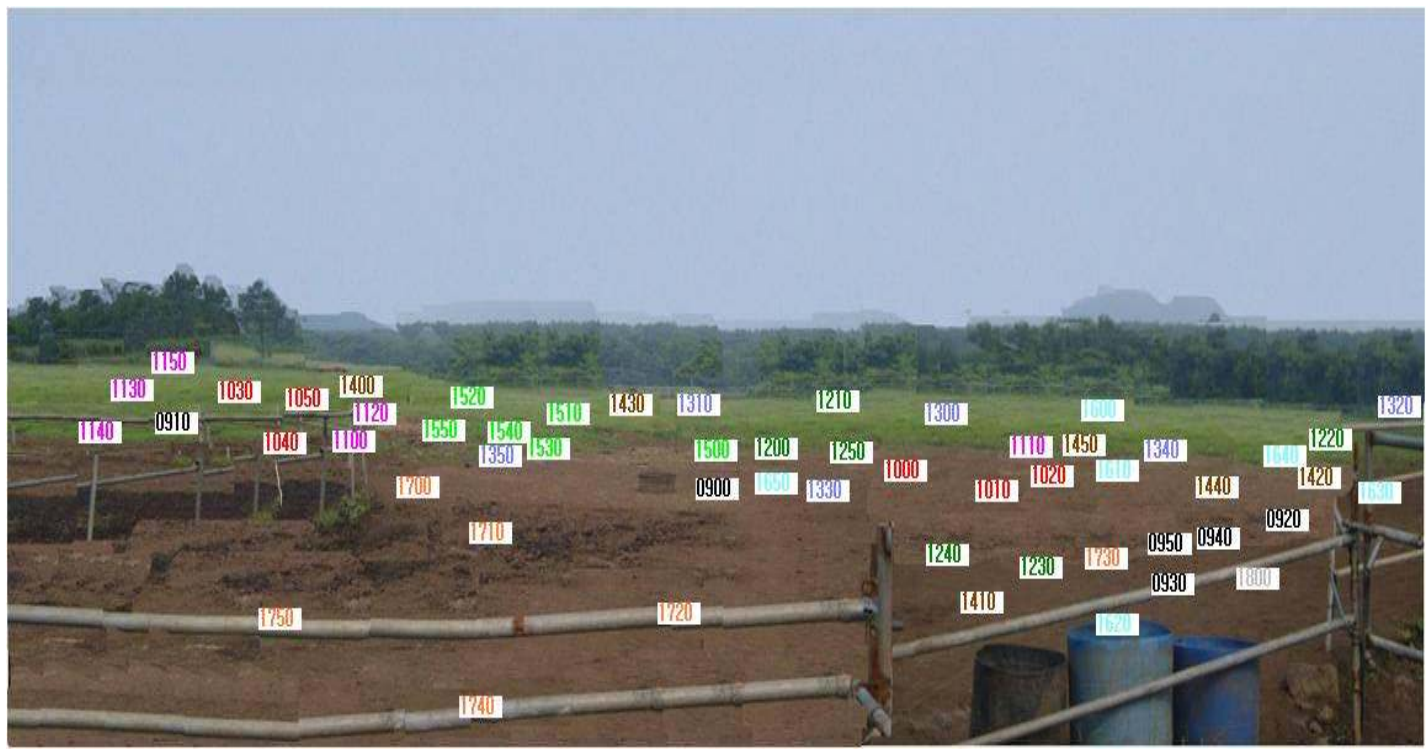

Fig. 1. Movement course of mare grazed in pasture. 

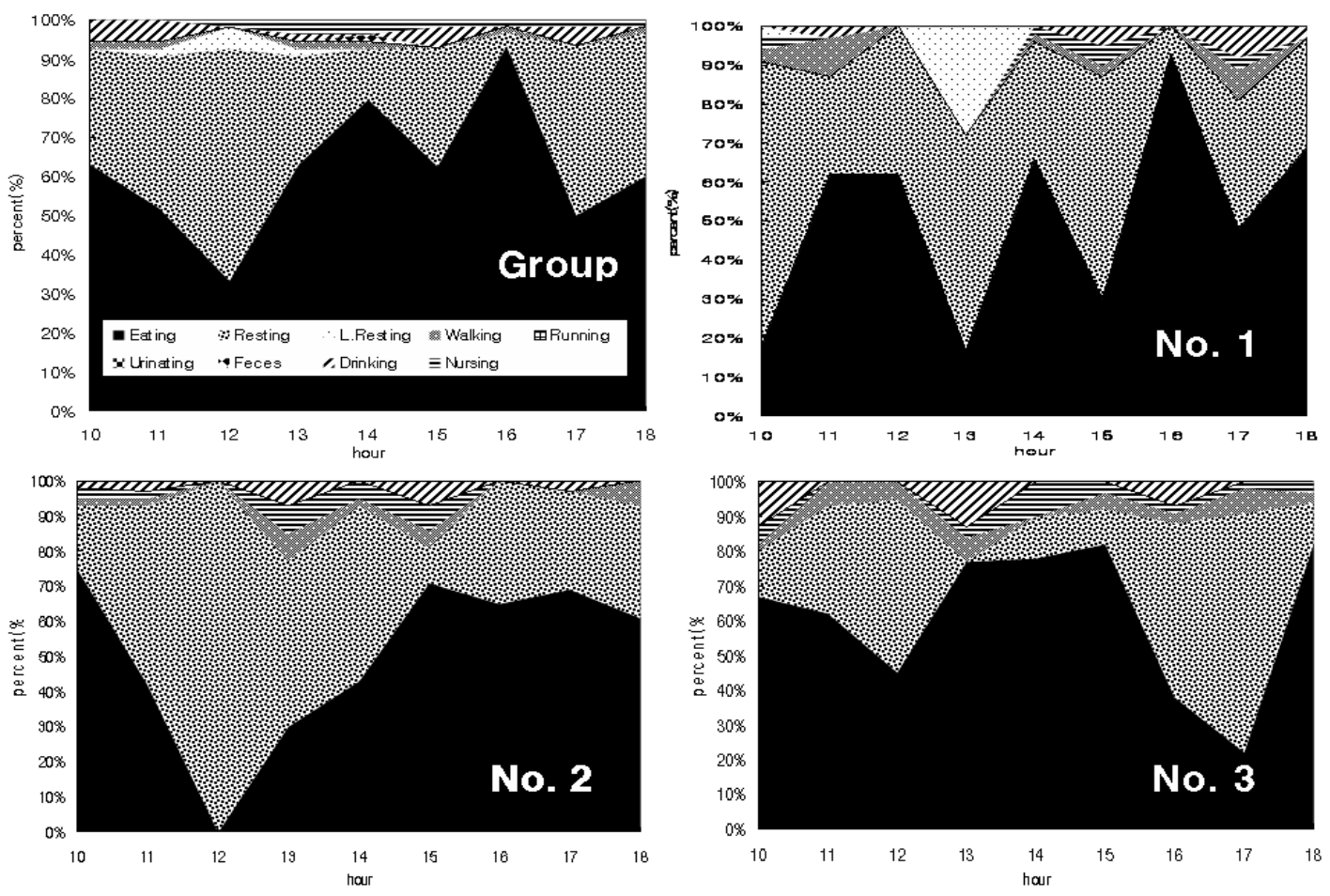

Fig. 2. Group and individual behavioral pattern of mare grazed in pasture.

빈마들이 많은 시간을 채식에 이용하는 것은 수유로 인해 많은 영양분을 필요로 하기 때문 인 것으로 여겨진다. 일반적으로 말의 채식행 동은 가장 기본적인 개체유지행동으로 선천적 으로 갖추어진 행동 인해 있으나 주어진 환경 로 말해 섭취하는 방법이 변화할 수 있다. 식 생조건이 나쁘면 1일 19 20시간을 채식행동에 소비한다고 하는 등 말의 채식시간은 사료의 질, 방목계절, 기온, 초지의 상태에 따라 달라 진다고 보고되고 있다 (三村, 1988). 한편 채식 행동을 제외하고는 많은 시간을 휴식에 소비하 는 것으로 조사되었는데 채식과 휴식이 같이 일어나는 경우가 많았다. 종빈마는 휴식 시에 도 거의 대부분을 서서 휴식을 하였고 개체별 로도 1 번 마는 19분 동안 누워서 휴식을 하였 으나 2 번과 3 번 마는 관찰하는 동안 누워서 휴 식을 취하지 않은 것으로 나타났다. 어미의 횡
와 휴식은 자마에 비해 현저히 낮은 것으로 알 려져 있는데 (Crowell-Davis, 1994) 이는 자마를 보호하기 위한 행동으로 여겨진다.

본 조사연구에서 보행과 러닝에 대한 발현이 적은 것은 종빈마의 경우 자마에게 다른 말이 접근해 오면 위협행동을 나타내기 때문에 서로 각 개체 간에 보행이나 런닝을 통한 접근을 하 지 않기 때문인 (三村, 1998) 것으로 분석된다. 또한 투쟁과 뒹굴기 행동은 전혀 나타나지 않 아 이 또한 자마를 보호하기 위한 행동발현으 로 여겨진다(Francis-Smith, 1979). 수유시간도 개체차가 많아 1 번 개체는 8 분이었던데 반해 2 번 개체는 15 분을, 3 번 개체는 17 분을 소비하 였다. 이러한 수유시간의 개체차는 자마의 생 후 연령 차이에 의한 것으로 생각된다. 수유시 간과 횟수는 자마가 성장함에 따라 단축된다고 보고되고 있다 (三村, 1988). 
Table 4. Time and ratio spent on each behavior of pregnancy horses in paddok

\begin{tabular}{|c|c|c|c|c|c|c|c|c|c|c|c|}
\hline \multirow{3}{*}{ Item } & \multirow{2}{*}{\multicolumn{2}{|c|}{ Eating }} & \multicolumn{5}{|c|}{ Resting } & \multirow{2}{*}{\multicolumn{2}{|c|}{ Walking }} & \multirow{2}{*}{\multicolumn{2}{|c|}{ Running }} \\
\hline & & & \multicolumn{3}{|c|}{ Standing } & \multicolumn{2}{|c|}{ Lying } & & & & \\
\hline & Min. & $\%$ & M & & $\%$ & Min. & $\%$ & Min. & $\%$ & Min. & $\%$ \\
\hline No.1 & 251 & 46 & 2 & & 46 & 3 & 1 & 29 & 5 & 1 & 0 \\
\hline No. 2 & 324 & 60 & 1 & & 33 & 1 & 0 & 29 & 5 & 0 & 0 \\
\hline No. 3 & 260 & 48 & 2. & & 43 & 1 & 0 & 38 & 7 & 1 & 0 \\
\hline Avg. & $\begin{array}{c}278.3 \pm \\
39.8\end{array}$ & $\begin{array}{c}51.3 \pm \\
7.6\end{array}$ & $\begin{array}{r}218 \\
35\end{array}$ & & $\begin{array}{c}40.7 \pm \\
6.8\end{array}$ & $\begin{array}{l}1.7 \pm \\
1.2\end{array}$ & $\begin{array}{l}0.3 \pm \\
0.5\end{array}$ & $\begin{array}{c}32.0 \pm \\
5.2\end{array}$ & $\begin{array}{l}5.7 \pm \\
1.2\end{array}$ & $\begin{array}{l}0.7 \pm \\
0.5\end{array}$ & 0 \\
\hline Group & & 44 & & & 48 & & 2 & & 4 & & 0 \\
\hline \multirow[t]{2}{*}{ Item } & \multicolumn{2}{|c|}{ Drinking } & \multicolumn{2}{|c|}{ Nursing } & \multicolumn{2}{|c|}{ Total } & Grooming & Urinating & Feces & Fighting & Rolling \\
\hline & Min. & $\%$ & Min. & $\%$ & Min. & $\%$ & No. & No. & No. & No. & No. \\
\hline No.1 & 9 & 2 & 0 & 0 & 540 & 100 & 18 & 0 & 1 & 1 & 4 \\
\hline No. 2 & 8 & 1 & 0 & 0 & 540 & 100 & 15 & 2 & 4 & 0 & 0 \\
\hline No. 3 & 10 & 2 & 0 & 0 & 540 & 100 & 12 & 1 & 3 & 1 & 1 \\
\hline Avg. & $\begin{array}{c}9.0 \pm \\
1.0\end{array}$ & $\begin{array}{c}1.7 \pm \\
0.5\end{array}$ & 0 & 0 & 540 & 100 & $\begin{array}{c}15.0 \pm \\
3.0\end{array}$ & $\begin{array}{l}1.0 \pm \\
1.0\end{array}$ & $\begin{array}{l}2.7 \pm \\
1.5\end{array}$ & $\begin{array}{l}0.7 \pm \\
0.5\end{array}$ & $\begin{array}{l}1.7 \pm \\
2.0\end{array}$ \\
\hline Group & & 2 & & 0 & & 100 & & & & & \\
\hline
\end{tabular}

Table 4는 패독 내에서 사육 중인 임신 중인 종빈마군의 행동 발현과 개체의 행동 발현 조 사결과를 나타낸 것이다. 임신 종빈마군에서는 서서 휴식하는 시간이 $48 \%$, 채식 $44 \%$, 횡와 $2 \%$, 보행 $4 \%$, 음수 $2 \%$ 로 나타났다. 임신 종빈 마 개체별 (3두) 평균 행동 발현 비율은 채식이 278 분으로 $52 \%$, 기립 218 분으로 $40 \%$, 보행 32 분으로 $6 \%$, running은 1분, 음수행동 9분으로 $2 \%$ 를 나타내었다. 임신 종빈마 개체별 grooming 은 15 회, 배뇨는 1 회, 배분은 3 회, 투쟁 1 회, 구 르기 2회로 조사되었다. 채식시간은 포유 종빈 마보다 짧았으며. grooming과 투쟁행동이 상대 적으로 많이 발현되었다. 패독에서 사육되고 있는 말이 방목장에 있는 말보다 grooming 횟 수와 투쟁행동이 많이 나타난 것은 방목장이
아닌 운동장이라는 상대적으로 좁은 환경과 지 루함을 해소하기 위해서 나타나는 행동으로 생 각된다.

패독에서의 임신 종빈마의 군별 이동패턴을 Fig. 3에, 시간대 별 임신 종빈마의 군행동과 각 개체의 행동발현을 Fig. 4에 각각 나타내었 다. 패독에서의 임신 종빈마의 이동경로는 패 독 가운데를 가로지르기 보다는 펜스 주변을 따라 이동하는 경향을 나타내었으며 옆 패독과 인접해 있는 곳에 집중되는 경향을 나타내었 다. 패독에 있는 임신 종빈마에서 대각선 방향 으로의 러닝 비율이 증가하는 경향을 보인다는 보고(Grete와 Knut, 2007)가 있는데 본 연구에 서는 상대적으로 패독의 크기가 작기 때문에 패독을 대각선방향으로 이동하기보다는 펜스주 


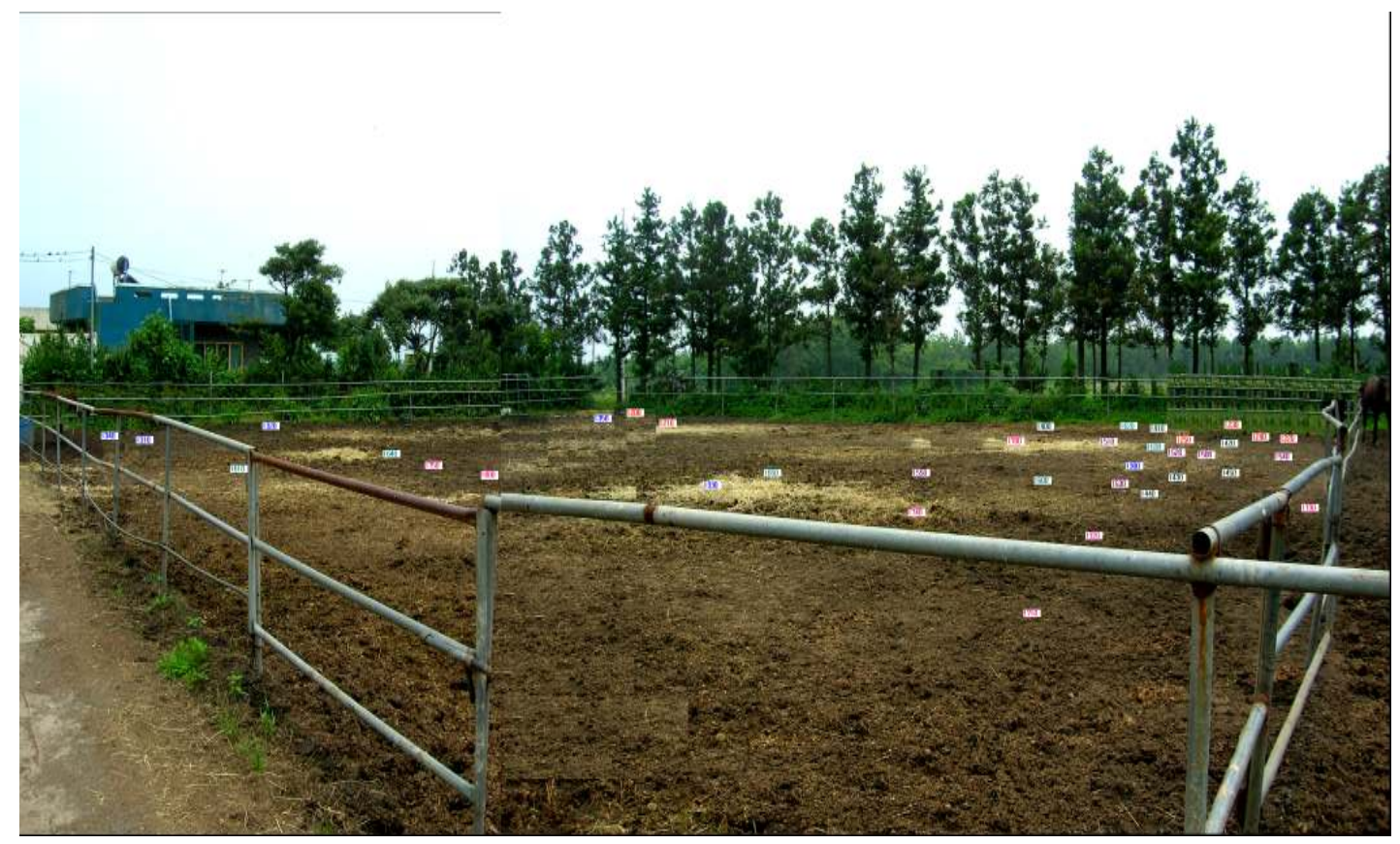

Fig. 3. Movement course of pregnancy horses in paddok.
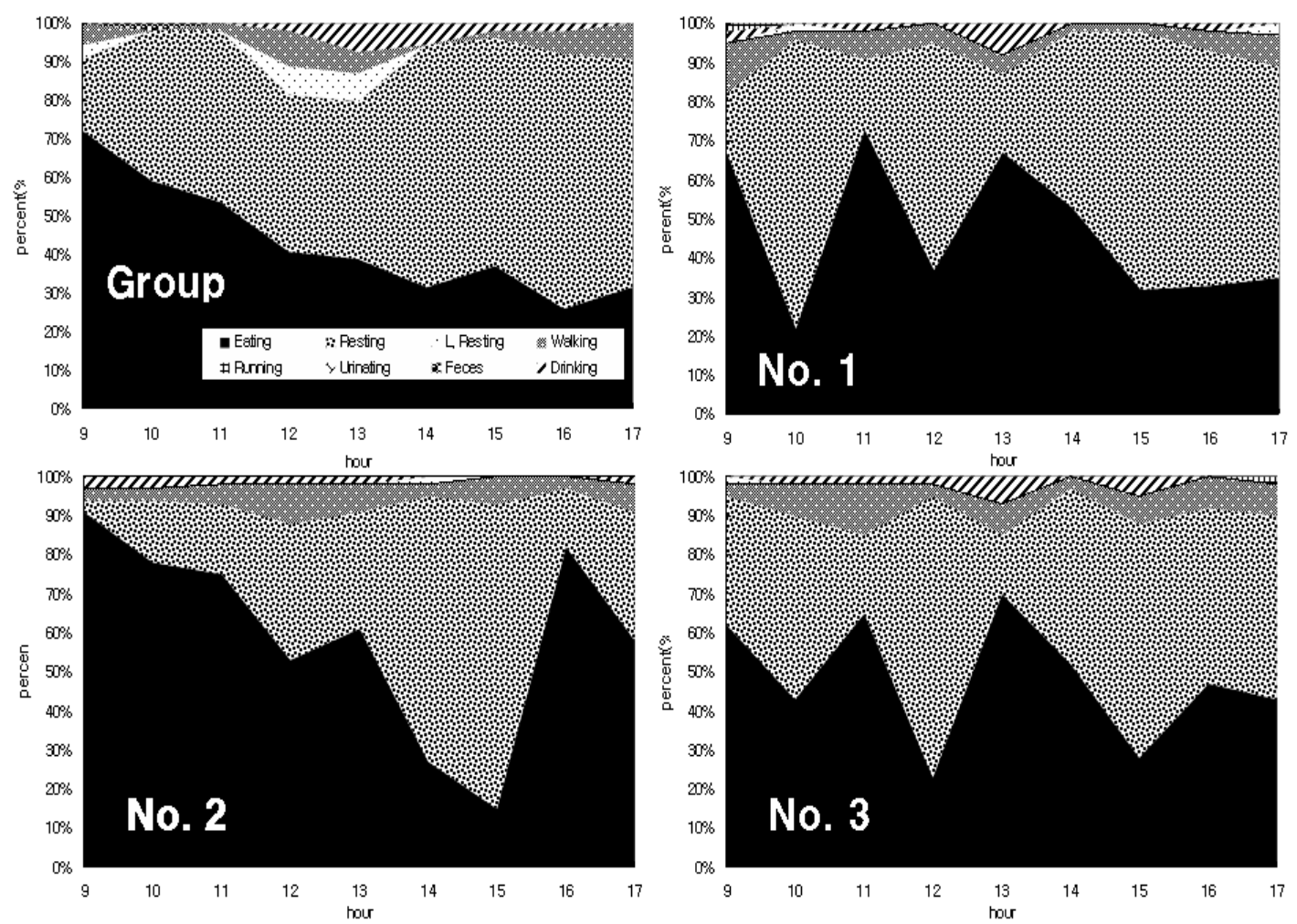

Fig. 4. Group and individual behavioral pattern of pregnancy horses fed in paddok. 
변을 따라 이동한 것으로 여겨진다.

임신 종빈마의 군행동에서 채식시간은 전체 적으로 오후보다 오전시간대에 집중되었고 오 후시간에는 휴식을 취하는 경향을 나타내었다. 개체별로 조사한 경우는 개체차이가 나타나 1 번 개체는 오전 11 시경과 오후 1 시 경에 채식 행동을 하였고 오후 3시 이후에는 휴식에 많은 시간을 소비하였으며 2 번 개체는 오전에 높은 채식행동을 하여 오후로 갈수록 시간이 줄어들 어 오후 3시 경에는 휴식을 취한 후 다시 오후 4 시경에 채식을 하였으며 3 번 개체는 채식과 휴식에 거의 비슷한 시간을 소비하여 오전 11 시경, 오후 1 시경에 채식을 하였으나 하루를 고르게 채식에 소비한 것으로 조사되었다. 전 체적으로 임신 종빈마는 채식과 휴식에 많은 시간을 소비하는 것으로 나타났다. 개체별로 채식행동에 차이가 나타난 것은 여러 가지 요 인이 있을 것이며 패독이라는 한정된 공간에서 말의 서열에 의한 차이일 수도 있을 것으로 생 각된다. 따라서 본 연구를 기초로 하여 앞으로 다양한 환경 하에서 말의 개체별 및 군별 행동 연구가 필요할 것이다.

\section{V. 요 약}

본 연구는 경주마 생산 육성에 중요한 종빈 마의 패독과 방목지에 있어 군별 및 개체별 행 동양식을 조사하여 경주마 사양관리의 기초자 료로 활용하기 위해 실시하였다. 방목 중인 포 유 종빈마군에서는 채식이 $62 \%$, 기립 휴식이 $31 \%$, 음수가 $3 \%$, 횡와 휴식이 $1 \%$, 보행이 $1 \%$, 수유 행동은 $2 \%$ 가 발현되었는데 러닝은 발현 되지 않았다. 포유 종빈마 개체별 (3필) 행동발 현비율의 평균은 채식이 295 분으로 $55 \%$, 기립 휴식이 193 분으로 $36 \%$, 보행과 음수가 각각 18 분, 15 분으로 $3 \%$, 수유가 13 분으로 $2 \%$, 횡와 휴식이 6 분으로 $1 \%$ 였다. 개체들은 평균적으로 grooming 11회, 배뇨 2회, 배분 1회의 행동발현 이 관찰되었다. 패독에서 관리 중인 임신 종빈 마 군에서는 기립 휴식이 $48 \%$, 채식 $44 \%$, 횡 와 휴식 $2 \%$, 보행 $4 \%$, 음수 $2 \%$ 를 발현하였다. 임신 종빈마 개체별 (3필) 발현 비율 평균은 채 식 $52 \%$, 기립 $40 \%$, 보행 $6 \%$, 음수 $2 \%$ 였다. 개 체들은 평균적으로 grooming 15회, 배뇨 1회, 배분 3회, 투쟁 1회, 구르기 2회의 행동발현이 관찰되었다. 이동패턴의 경우 옆 패독과 인접 해 있는 곳에 집중되는 경향을 보였다.

$$
\mathrm{V} \text {. 사 사 }
$$

이 논문은 2008년도 건국대학교 학술진흥연 구비 지원에 의한 논문임.

\section{VI. 인 용 문 헌}

1. 강민수, 고봉석, 김희건, 양경우, 정광조, 고성방. 1996. 제주마에 관한 조사연구 III. 제주마 종빈 마의 방목습성(2). 한국동물자원과학회. 초록. PA9641.

2. 정창조, 강민수, 하정찬. 1994 . 제주재래마의 방 목습성에 관한 연구. 한국축산학회지. 36(4):428433.

3. Carson, K.D. and G.M.D. Wood-Gush. 1983. Equine behaviour. II. A review of the literature on feeding, eliminative and resting behaviour. Appl. Anim. Ethol. 10:179-190.

4. Crowell-Davis, S.L., K.A. Houpt and J. Carnevale. 1985. Feeding and drinking behaviour of mares and foals with free access to pasture and water. J. Anim. Sci. 60:883-889.

5. Crowell-Davis, S.L. 1994. Daytime rest behavior of the Welsh pony (Equus caballus) mare and foal. Appl. Anim. Behav. Sci. 40: 197-210.

6. Feist, J.D. and D.R. McCullough. 1976. Behaviour patterns and communication in feral horses. Z. Tierpsychol., 41:337-371.

7. Filipa, H., M.O. Maria and V. Luis. 2006. Social 
relationship in herd of Sorraia horses.

8. Francis-Smith, K. 1979. Studies on the feeding and social behaviour of domestic horses. Ph. D. Thesis, University of Edinburgh.

9. Grete, H.M.J. and E.B. Knut. 2007. A note on the effect of daily exercise and paddock size on the behaviour of domestic horses (Equus caballus). Appl. Anim. Behav. Sci. 107:166-173.

10. Hector, R. 1990. Social Facilitation in the Horse (Equus cabaUus). Appl. Anim. Behav. Sci. 25: 167-176.

11. Houpt, K.A. 1977. Horse behaviour: its relevancy to the equine practitioner. J. Equine Med. Surg., 1:87-94.

12. Luescher, U.A., D.B. McKeown and J. Halip. 1991. Reviewing the causes of obsessivecompulsive disorders in horses. Vet. Med. 86: 527-530.

13. Schafer, M. 1975. The Language of the Horse. Habits and Forms of Expression. Kaye and Ward, London.

14. Sheppard, J.H. 1921. Dak. Agric. Exp. Stn., Bull.
No. 154. Cited by Tribe, D.E., 1955.

15. Thorpe, W.H. 1963. Learning and Instinct in Animals. 2nd. Edn. Methuen, London, pp. 558.

16. Tsujii, H. and T. Asai. 1985. The behaviour of Kiso horses under housing of five successive days. J. Fac. Agri. Shinshu Uni. 22:21-29.

17. Tsujii, H. and M. Moro. 1987. Rest behaviour of Kiso horse foal. J. Fac. Agri. Shinshu Uni. 24:81-87.

18. Tyler, S.J. 1972. The behaviour and social organisation of the New Forest ponies. Anim. Behav. Monogr. 5:85-196.

19. Waring, G.H., S. Wierzbowski and E.S.E. Hafez. 1975. The behaviour of horses. In: E.S.E. Hafez (Editor), The Behaviour of Domestic Animals. 3rd edn., Balliere, Tindall and Cassell, London, Chap. 13.

20. 三村 耕. 1988. 家畜行動學. 瀁賢堂. 東京.

(접수일: 2009년 9월 16일, 수정일 1차: 2009년 11월 5일, 수정일 2차: 2009년 11월 20일, 게재확정일: 2009년 12월 8일) 